\title{
PENGARUH JENIS MEDIA KULTUR TERHADAP KONSENTRASI BIOMASSA Nannochloropsis sp.
}

\author{
Nabila Marthia \\ Program Studi Teknologi Pangan Fakultas Teknik Universitas Pasundan, Jl. Dr. Setiabudhi No. 193, Bandung, 40153, \\ Indonesia.
}

Email : nabilamarthia@unpas.ac.id

\begin{abstract}
Abstrak
Penelitian ini bertujuan untuk mengetahui pengaruh jenis media terhadap konsentrasi biomassa dan kandungan klorofil pada Nannochloropsis sp. dan menentukan jenis media terbaik untuk produksi klorofil tertinggi pada mikroalga tersebut. Variabel yang diamati antara lain pertumbuhan dan waktu panen optimum Nannochloropsis sp. dan konsentrasi biomassa Nannochloropsis sp., dan kadar klorofil hasil ekstraksi biomassa. Hasil penelitian menunjukkan bahwa nilai konsentrasi biomassa basah Nannochloropsis sp. sebesar 10,98 g/L untuk media Walne, dan 5,10 g/L untuk media Guillard. Kandungan klorofil hasil ekstraksi dari biomassa kering pada mikroalga Nannochloropsis sp. dengan media kultur Walne lebih tinggi dibandingkan dengan media Guillard dengan total klorofil senilai 353,045 $\mu \mathrm{g} / \mathrm{mL}$. Sehingga produksi klorofil terbaik adalah kultivasi menggunakan media kultur Walne.
\end{abstract}

Kata kunci : mikroalga, pigmen klorofil, kultur

\section{Pendahuluan}

Mikroalga merupakan organisme mikroskopik uniseluler atau multiseluler yang hidup dari nutrien anorganik dan produksi zat organik yang berasal dari proses fotosintesis (Isnansetyo dan Kurniastuty, 1995). Mikroalga hidup secara berkoloni, berfilamen, atau helaian pada kondisi tunggal (Stanley, 2000). Mikroalga banyak dijumpai pada perairan yang besar seperti pada laut, danau, sungai, serta perairan payau.

Keragaman mikroalga di dunia diperikirakan berada dalam kisaran jutaan spesies, sebagian besar belum dikenali sehingga belum bisa dikultivasi (Hadiyanto et al., 2013). Biomassa dari proses kultivasi mikroalga dapat menghasilkan produk tertentu, seperti pigmen karotenoid, pigmen klorofil, enzim, protein, lipid, dan karbohidrat (Cardozo et al., 2007).

Jika dilihat dari segi nutrisinya, mikroalga ini dapat berpotensi untuk dimanfaatkan biomassanya sebagai sumber nutrisi pangan. Namun, kenyataannya respon masyarakat di Indonesia terhadap mikroalga sebagai sumber pangan alternatif belum terlalu berkembang, padahal nutrisi mikroalga cukup tinggi dibandingkan dengan sumber pangan yang selama ini dikonsumsi.

Nannochloropsis sp. merupakan salah satu jenis mikroalga yang banyak mengandung nutrisi, antara lain : protein $(52,11 \%)$, karbohidrat $(16,00 \%)$, lemak (27,64\%), dan pigmen klorofil (0,89\%) (Riedel, 2009). Dengan demikian Nannochloropsis sp. mempunyai potensi besar sebagai sumber nutrisi pangan.

Pemanfaatan biomassa mikroalga untuk menjadi sumber nutrisi pangan bergantung pada proses pertumbuhan mikroalga. Biomassa yang diinginkan adalah biomassa yang dihasilkan dalam jumlah banyak dan kandungan nutrisinya sesuai.

Adapun faktor nutrien merupakan salah satu faktor penting yang perlu diperhatikan dalam proses pertumbuhan mikroalga. Nutrien yang dibutuhkan oleh mikroalga terdiri dari makronutrien dan mikronutrien. Makronutrien yang dibutuhkan antara lain : C, H, N, P, $\mathrm{K}, \mathrm{S}, \mathrm{Mg}$, dan Ca. Sedangkan mikronutrien yang dibutuhkan antara lain : $\mathrm{Cu}, \mathrm{Fe}, \mathrm{Co}, \mathrm{Mn}, \mathrm{Zn}, \mathrm{Mo}, \mathrm{Vn}$, dan Si (Kawaroe et al., 2010). Aspek nutrisi ini akan berpengaruh terhadap kuantitas biomassa yang dihasilkan.

Penelitian ini akan menggunakan dua jenis media kultur sebagai nutrisi untuk mikroalga, antara lain : media Walne, dan media Guillard . Media Walne sendiri merupakan media yang umum digunakan dalam proses pertumbuhan mikroalga. Media Walne dan media Guillard sama-sama memiliki trace element yang dibutuhkan untuk memproduksi pigmen klorofil.

Selain protein, Nannochloropsis sp. memiliki potensi sebagai sumber klorofil. Klorofil merupakan pigmen yang memiliki banyak manfaat. Selain menjadi pewarna alami, klorofil juga merupakan komponen fungsional yang dapat berperan sebagai antioksidan, antikanker, antihipertensi, antiinflamasi, dll. Selama ini penelitian tentang media yang tepat untuk konsentrasi biomassa dan kandungan klorofil pada Nannochloropsis $s p$. belum banyak dipublikasikan. Penelitian yang sudah dilakukan lebih terfokus kepada kandungan protein dan asam lemak. 


\section{Bahan dan Metode Penelitian}

Bahan- bahan yang digunakan dalam penelitian ini meliputi starter mikroalga Nanncochloropsis $s p$. usia 60 jam dengan media kultur yang digunakan adalah media Walne dan media Guillard.

\section{Metode Penelitian}

Penelitian Pendahuluan

Penelitian pendahuluan yang dilakukan yaitu menentukan kurva pertumbuhan dan waktu panen optimum.

Kultur Starter Nannochloropsis sp. dengan perbandingan air laut dan starter 70:30 dengan kepadatan awal starter $2,5 \times 10^{6} \mathrm{sel} / \mathrm{mL}$. Salinitas air sebesar 28-30 ppt, intensitas cahaya 2500-2800 lux, dan suhu yang digunakan $28-30^{\circ} \mathrm{C}$. Lakukan di dalam botol kaca steril 1 Liter. Berikan aerasi secara terus-menerus selama proses kultivasi. Selama proses kultivasi lakukan pengamatan terhadap pertumbuhan setiap hari $(1 \times 24$ jam $)$ dengan menggunakan haemacytometer.

Hasil pengamatan digunakan sebagai kurva pertumbuhan dan penentuan waktu pemanenan optimum. Waktu pemanenan optimum ditentukan pada saat kultur Nannochloropsis sp. berada pada fase eksponensial karena pada akhir fase eksponensial Nannochloropsis $s p$. mengalami puncak pertumbuhan dan kelimpahan biomassa atau kepadatan sel (Kawaroe et al., 2010).

\section{Penelitian Utama}

Penelitian utama dilakukan untuk produksi biomassa Nannochloropsis sp. pada berbagai jenis media.

Kultivasi Nannochloropsis sp. sebanyak 6 Liter dengan menggunakan aquarium yang sudah steril. Perbandingan air laut dan starter Nannochloropsis sp. adalah 70:30. Kepadatan awal starter yang digunakan dalam kultivasi sebesar $2,8 \times 10^{6} \mathrm{sel} / \mathrm{mL}$. Salinitas air yang digunakan sebesar 2500-2800 lux, dan suhu yang digunakan $28-30^{\circ} \mathrm{C}$. Masing-masing aquarium yang berisi air laut dan starter Nannochloropsis sp. ditambahkan media kultur sesuai perlakuan. Media Guillard dan media Walne ditambahkan ke dalam masing-masing aquarium sebanyak $1 \mathrm{~mL} / \mathrm{L}$. Pengamatan terhadap biomassa sel Nannochloropsis sp. dilakukan pada hari ke-0 dan pada saat panen sesuai waktu panen optimum dengan menggunakan haemacytometer. Biomassa dipisahkan yang mengendap dengan air dan media kulturnya. Kemudian cuci hingga salinitasnya 0 ppt. Setelah mendapatkan biomassa murni, lalu keringkan dengan freeze dryer.

Sediaan mikroalga berupa serbuk ditimbang dan dimaserasi dengan menggunakan pelarut etanol (1:10, w/v). Ekstraksi dilakukan sebanyak tiga kali. Hasil ekstraksi kemudian disaring dan dipekatkan dengan rotary evaporator pada suhu $40^{\circ} \mathrm{C}$ (Pangestuti, 2017).

Rancangan respon yang akan diamati terhadap biomassa kering mikroalga adalah pertumbuhan dan waktu panen optimum Nannochloropsis sp., konsentrasi biomassa Nannochloropsis sp.

\section{Hasil dan Pembahasan \\ Penelitian Pendahuluan}

Mikroalga Nannochloropsis sp. dikultivasi dalam $900 \mathrm{~mL}$ air laut steril dan salinitas 28 ppt dengan kepadatan 1,2 × $10^{6} \mathrm{sel} / \mathrm{mL}$. Kultivasi mikroalga membutuhkan waktu 7-14 hari dalam laboratorium untuk memasuki fase eksponensial hingga fase kematian dengan suhu $27-29^{\circ} \mathrm{C}$.

Media kultivasi yang digunakan pada mikroalga Nannochloropsis sp. ini ada 2 jenis, yaitu media Walne dan media Guillard. Proses kultivasi hanya menggunakan nutrien awal yang diberikan dalam media masing-masing tanpa adanya penambahan nutrien selama kultivasi berlangsung.

Berdasarkan hasil penelitian mengenai pengaruh penggunaan media yang berbeda terhadap laju pertumbuhan mikrolaga Nannochloropsis sp., menunjukan bahwa laju pertumbuhan Nannochloropsis $s p$. menggunakan media Walne relatif lebih tinggi dibandingkan dengan media Guillard. Peningkatan laju pertumbuhan selama pengamatan dapat dilihat pada Gambar 1.

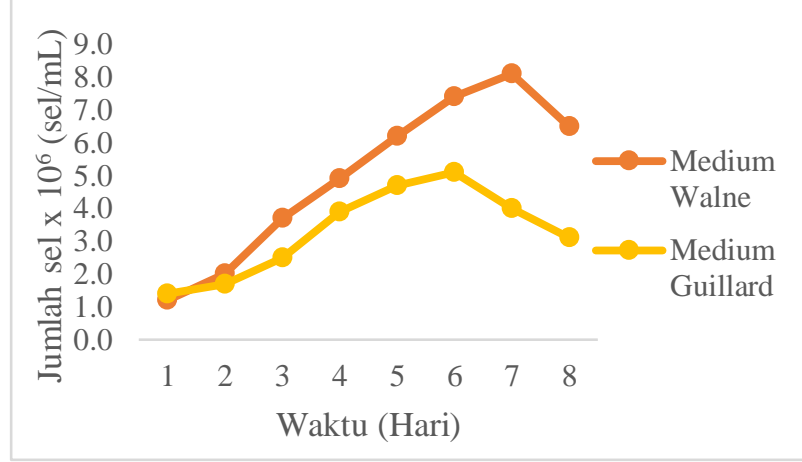

Gambar 1. Kurva Laju Pertumbuhan Nannochloropsis sp. dengan media Walne dan media Guillard.

Jika dilihat kurva pada Gambar 1, fase yang terjadi dapat dibagi menjadi lima fase yang meliputi fase lag, fase eksponensial, fase penurunan kecepatan pertumbuhan, fase stasioner, dan fase kematian. Titik tertinggi laju pertumbuhan Nannochloropsis $s p$. dengan media pertumbuhan Walne terjadi pada hari ketiga yaitu $3,70 \times 10^{6} \mathrm{sel} / \mathrm{mL}$ dengan persentase laju pertumbuhan 85\% yang menandakan bahwa Nannochloropsis sp. berada pada fase eksponensial. Fase stasioner berada antara hari ke-4 hingga hari ke-7, dan fase kematian terjadi pada hari ke-8 yaitu terjadi penurunan jumlah Nannochloropsis sp. dari hari ke-7 sebanyak 8,10 x $10^{6}$ $\mathrm{sel} / \mathrm{mL}$ menjadi $6,50 \times 10^{6} \mathrm{sel} / \mathrm{mL}$.

Pada penggunaan media Guillard, fase lag (adaptasi) teramati yaitu pada hari ke-3. Fase eksponensial terjadi pada hari ke-4 dengan jumlah sel yang dihasilkan 3,90 x $10^{6} \mathrm{sel} / \mathrm{mL}$ dengan persentase laju pertumbuhan sebesar 56\%. Fase stasioner terjadi sejak hari ke-5 hingga hari ke-6 dengan persentase laju pertumbuhan sekitar $21 \%$ dan 9\%. Mikroalga Nannochloropsis sp. mengalami fase kematian pada hari 
ke-7 dengan penurunan persentase laju pertumbuhan sebanyak $22 \%$ dari hari ke-5 dan penurunan kembali dialami Nannochloropsis sp. pada hari ke-8 dengan penurunan persentase laju pertumbuhan sebesar $23 \%$.

\section{Penelitian Utama}

Pada proses kultivasi Nannochloropsis sp.dilakukan menggunakan media Walne dan Guillard sebagai sumber nutriennya. Adapun kurva pertumbuhan yang dihasilkan dari kultivasi dapat dilihat pada Gambar 2 dan Gambar 3.

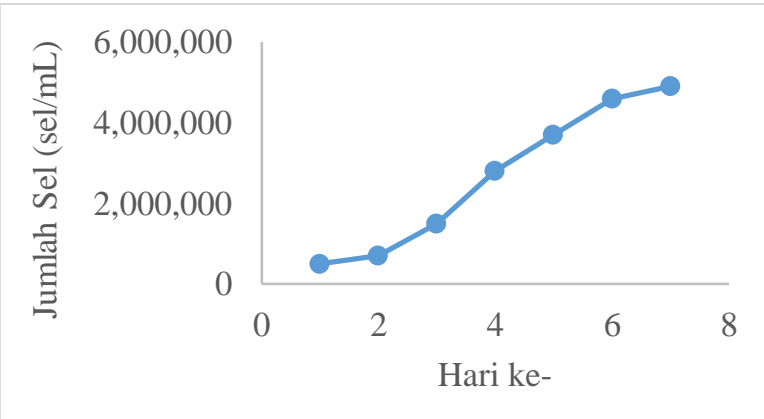

Gambar 2. Kurva Pertumbuhan Nannochloropsis sp. pada media Walne.

Kultivasi Nannochloropsis sp. menggunakan media Walne memiliki umur 7 hari. Kurva pertumbuhan Nannochloropsis $s p$. menunjukkan kultur memasuki fase logaritmik hingga hari ke-6 yang ditunjukkan pada Gambar 2, dengan peningkatan log kepadatan sel dari 1,50-4,60 sel/mL. Hari berikutnya sel tidak mengalami peningkatan yang signifikan dengan log kepadatan sel berada pada kisaran 4,60-4,90 sel/mL hingga pengamatan hari ke-7.

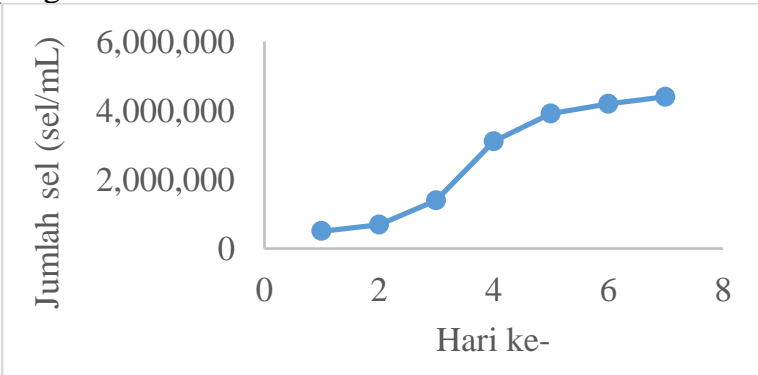

Gambar 3. Kurva Pertumbuhan Nannochloropsis sp. pada media Guillard.

Pada Gambar 3 dapat dilihat bahwa kultivasi Nannochloropsis sp. menggunakan media Guillard memiliki umur 7 hari. Kultur Nannochloropsis sp. pada media Guillard teramati mengalami fase adaptasi yang terjadi pada hari ke-2 dengan log kepadatan sel 0,70 $\mathrm{sel} / \mathrm{mL}$. Hal tersebut terjadi karena mikroalga Nannochloropsis sp. mengalami penyesuaian dengan kondisi lingkungan pada media Guillard. Menurut Prayitno (2016), pada fase adaptasi, sel-sel yang membelah masih sedikit sehingga jumlah sel tidak mengalami peningkatan. Kultur Nannochloropsis sp. juga mengalami fase logaritmik hingga hari ke-7 yang ditunjukkan pada Gambar 3 dengan peningkatan log kepadatan sel dari 1,40-4,40 sel/mL hingga hari ke-7.

Peran nutrien dalam siklus kultur Nannochloropsis sp. sangat penting dimana nutrien sangat berpengaruh dalam pertumbuhan sel. Adanya kandungan senyawa $\mathrm{Na}_{2} \mathrm{SiO}_{3}$ pada media Walne dan Guillard berperan dalam pembentukan dinding sel dan cangkang mikroalga. Selain itu terdapat $\mathrm{FeCl}_{3}$ yang akan mereduksi nitrat menjadi nitrit dan berhubungan dengan kandungan protein pada mikroalga tersebut. Protein ini berperan dalam proses pertumbuhan dan regenerasi sel dari mikroalga.

Derajat keasaman $(\mathrm{pH})$ air laut yang digunakan merupakan faktor yang harus diperhatikan. Nannochloropsis $s p$. dapat tumbuh dengan baik pada $\mathrm{pH}$ berkisar antara 5,5-8,5 dengan $\mathrm{pH}$ optimum untuk fotosintesis adalah 6

Selain derajat keasaman, salah satu faktor lingkungan yang penting dalam kultivasi mikroalga adalah cahaya. Cahaya berperan utama dalam proses fotosintesis. Adapun kultivasi Nannochloropsis sp. pada penelitian ini menggunakan intensitas cahaya 2400 lux. Intensitas cahaya ini akan berpengaruh terhadap pertumbuhan sel. Pertumbuhan sel yang optimum akan menghasilkan jumlah sel yang optimum dan akan berpengaruh terhadap jumlah biomassa yang dihasilkan.

Proses pemanenan pada penelitian ini diawali dengan proses pengendapan sebelum dilakukan sentrifugasi. Umumnya pemisahan biomassa Nannochloropsis sp. dilakukan melalui sentrifugasi untuk mendapatkan biomassa dari suatu kultur, namun tahap pengendapan dapar dilakukan agar proses mendapatkan biomassa lebih efisien. Hal ini dilakukan agar biomassa dalam cairan yang disentrifugasi lebih banyak terkonsentrasi sehingga mempermudah proses pemanenan.

Adapun proses pengendapan dilakukan dalam lemari pendingin agar kultur tidak mengalami pertumbuhan lebih lanjut setelah pemanenan. Kultur dipanen pada fase stasioner, yaitu pada hari ke-7. Proses pengendapan membentuk 2 lapisan, yaitu lapisan biomassa di bagian bawah dan lapisan cairan media di bagian atas.

Hasil pengendapan kemudian dikumpulkan dan disentrifugasi menggunakan sentrifuse dingin dengan suhu $4^{\circ} \mathrm{C}$ dan kecepatan $4000 \mathrm{rpm}$ selama 30 menit. Proses sentrifugasi ini menyebabkan biomassa terkumpul sehingga memudahkan dalam pemisahan biomassa. Proses pengeringan dengan cara freeze dryer dilakukan untuk mengeringkan biomassa basah Nannochloropsis $s p$. Proses ini dilakukan untuk mengurangi kadar air pada biomassa, dan dilakukan selama 8 jam.

Proses pengeringan freeze dryer ini cocok diaplikasikan untuk biomassa mikroalga karena menggunakan suhu rendah dan tekanan yang terkendali, sehingga komponen pigmen yang diinginkan dari biomassa Nannochloropsis sp. ini tidak mengalami kerusakan akibat suhu tinggi. 
Jumlah biomassa basah dan biomassa kering yang didapat dari kultivasi Nannochloropsis sp. pada media Walne dan Guillard dapat dilihat pada Tabel 1 berikut :

Tabel 1. Jumlah Biomassa Basah dan Biomassa Kering Nannochloropsis sp. pada Jenis Media yang Berbeda

\begin{tabular}{|l|c|c|c|c|c|}
\hline Jenis Media & $\begin{array}{c}\text { Bobot } \\
\text { Biomassa } \\
\text { Basah (gram) } \\
\text { per 15 L }\end{array}$ & $\begin{array}{c}\text { Konsentrasi } \\
\text { Biomassa Basah } \\
(\mathbf{g} / \mathbf{L})\end{array}$ & $\begin{array}{c}\text { Bobot } \\
\text { Biomassa } \\
\text { Kering (gram) } \\
\text { per 15 L }\end{array}$ & $\begin{array}{c}\text { Konsentrasi } \\
\text { Biomassa Kering } \\
(\text { g/L) }\end{array}$ & $\begin{array}{c}\text { Rendemen } \\
\text { Biomassa } \\
\text { Kering }(\%)\end{array}$ \\
\hline Walne & 50,4345 & 3,36 & 5,5402 & 0,37 & 10,98 \\
\hline Guillard & 10,6270 & 0,71 & 0,8420 & 0,06 & 5,10 \\
\hline
\end{tabular}

Komponen pigmen yang ingin dipisahkan dari biomassa mikroalga Nannochloropsis sp. ini diperoleh melalui ekstraksi bertingkat menggunakan pelarut dengan tingkat kepolaran berbeda. Pelarut yang berbeda digunakan untuk mendapatkan ekstrak yang lebih murni sehingga komponen pigmen terbebas dari komponen lain yang dapat mengganggu pengujian.

Proses ektraksi dimulai dari pemisahan pigmen-pigmen non polar, dimana biomassa kering mikroalga Nannochloropsis sp. diekstraksi menggunakan aseton dingin dengan perbandingan 3:1 (v/b). Proses ekstraksi pigmen non polar dapat dilihat pada Gambar 4.

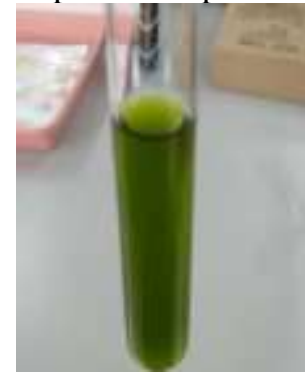

Gambar 4. Hasil Ekstraksi Pigmen Non Polar Nannochloropsis sp.

Setelah diekstraksi beberapa kali, proses berikutnya adalah sonikasi untuk memecah sel mikroalga dengan siklus sebanyak 10 kali (3 menit pengocokan dan 1 menit istirahat). Proses ini dilakukan di dalam penangas es. Suspensi hasil sonikasi kemudian disentrifus dan disaring untuk menghilangkan debris. Supernatan atau ekstrak kasar aseton yang dihasilkan akan dimurnikan dengan metode kromatografi kolom. Proses sonikasi dapat dilihat seperti pada Gambar 5.

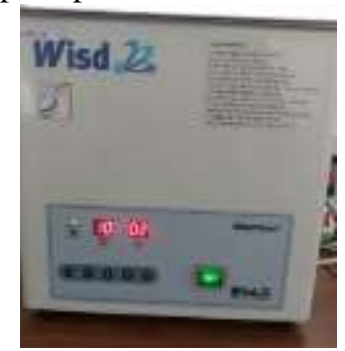

Gambar 5. Proses Sonikasi Ekstrak Kasar Aseton Nannochloropsis sp.

Ekstrak kasar dari pigmen-pigmen non polar diidentifikasi terlebih dahulu sebelum dilakukan pemisahan dengan kromatografi kolom. Identifikasi ekstrak kasar aseton dilakukan dengan metode Kromatografi Lapis Tipis (KLT). Pelat KLT diberi tanda batas atas $(0,5 \mathrm{~cm})$ dan bawah $(1,5 \mathrm{~cm})$. Totolan ekstrak diberi jarak sekitar $1 \mathrm{~cm}$. Proses elusi dilakukan di dalam sebuah wadah yang berisi eluen aseton : $n$-heksana $=3: 7$ (v/v) (Pavia, et al., 1999).

Proses kerja KLT ini adalah silika gel sebagai fase diam dapat membentuk ikatan hidrogen pada permukaannya. Pada permukaan silika gel terdapat gugus hidroksil dan bersifat sangat polar sehingga dapat membentuk ikatan hidrogen. Fase gerak yang digunakan yaitu eluen yang terdiri dari campuran aseton dan nheksana, dimana kedua pelarut tersebut bersifat nonpolar. Jika pigmen yang ditotolkan pada permukaan silika gel dan dimasukkan ke dalam fase gerak, maka senyawa yang bersifat polar akan bertahan pada fase diam. Sedangkan senyawa yang bersifat sedikit polar atau non-polar akan terbawa oleh fase gerak dengan cepat.

Untuk mengidentifikasi pigmen yang terkandung dalam sampel ekstrak kasar aseton yang dianalisis maka digunakan faktor reterdasi atau retardation factor (Rf). Untuk menghitung nilai Rf pada hasil KLT diperoleh dari perbandingan jarak yang ditempuh pigmen dengan jarak yang ditempuh pelarut.

Tabel 2. Nilai Rf Pigmen pada Ekstrak Kasar Aseton

\begin{tabular}{|c|c|c|c|}
\hline Spot & Nilai Rf & Warna & $\begin{array}{c}\text { Jenis } \\
\text { Pigmen }\end{array}$ \\
\hline 1 & 0,60 & Hijau & Klorofil a \\
\hline 2 & 0,32 & $\begin{array}{c}\text { Hijau } \\
\text { kuning }\end{array}$ & Klorofil b \\
\hline
\end{tabular}

Hasil penelitian menunjukkan nilai $\mathrm{Rf}$ yang berbeda-beda, dimana Rf karotenoid 0,98, Rf klorofil $a$ 0,60, dan Rf klorofil $b$ 0,32. Kisaran nilai Rf klorofil a (hijau) dan klorofil b (hijau kuning) memiliki kecenderungan sama dengan hasil penelitian lain yang memiliki nilai Rf klorofil $a$ 0,40-0,63, dan klorofil $b$ 0,30-0,57.

Setelah dilakukan proses Kromatografi Lapis Tipis (KLT), pigmen di dalam ekstrak kasar aseton dimurnikan dengan metode Kromatografi Kolom. Fase diam yang digunakan yaitu silika gel 7733, sedangkan fase geraknya menggunakan eluen yang sama seperti proses KLT. 
Untuk memperkuat hasil kromatografi Lapis Tipis (KLT), selanjutnya untuk mengidentifikasi pigmen menggunakan metode Spektrofotometri. Metode ini memiliki hasil yang lebih akurat jika dibandingkan dengan metode KLT. Analisis spektrofotometri pada panjang gelombang 300-600 nm berhasil mendeteksi beberapa puncak pada ekstrak aseton dari biomassa mikroalga Nannochloropsis sp. Hasil identifikasi pigmen dari ekstrak aseton tersebut yaitu dari golongan klorofil dan karotenoid.

Klorofil a ditemukan pada puncak di dalam grafik dengan panjang gelombang $634 \mathrm{~nm}$. Panjang gelombang ini dapat disesuaikan dengan referensi dalam Jeffrey et al (1975), yaitu 430, 616, dan $662 \mathrm{~nm}$.

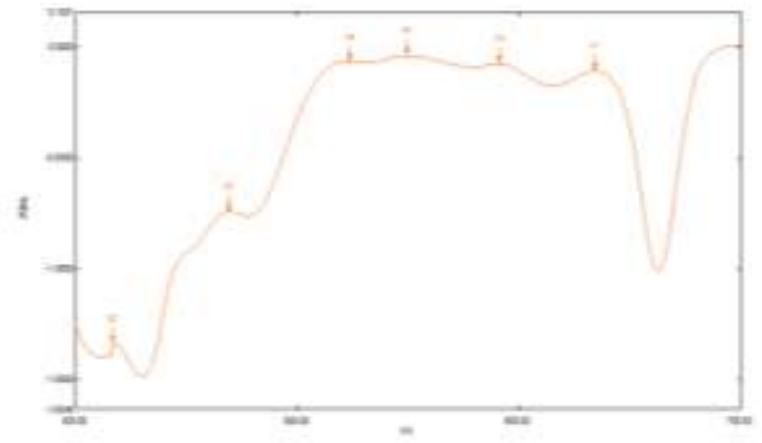

\section{Gambar 6. Hasil Spektrofotometer UV-Visibel klorofil $a$ hasil isolasi.}

Pengukuran kandungan klorofil dalam biomassa dari masing-masing mikroalga dilakukan menggunakan alat spektrofotometer UV-Visibel pada panjang gelombang $645 \mathrm{~nm}$ dan $663 \mathrm{~nm}$. Adapun kadar klorofil hasil ekstraksi biomassa mikroalga Nannochloropsis sp. dapat dilihat pada Tabel 3.

Tabel 3. Kadar klorofil hasil ekstraksi dari biomassa Nannochloropsis $s p$.

\begin{tabular}{|c|c|c|c|c|}
\hline $\begin{array}{c}\text { Jenis } \\
\text { Media }\end{array}$ & $\begin{array}{c}\text { Biomassa } \\
\text { kering } \\
(\mathbf{g})\end{array}$ & $\begin{array}{c}\text { Jumlah } \\
\text { klorofil } \\
\mathbf{a} \\
(\boldsymbol{\mu g} / \mathbf{m L})\end{array}$ & $\begin{array}{c}\text { Jumlah } \\
\text { klorofil } \\
\mathbf{b} \\
(\boldsymbol{\mu g} / \mathbf{m L})\end{array}$ & $\begin{array}{c}\text { Total } \\
\text { Klorofil } \\
(\boldsymbol{\mu g} / \mathbf{m L})\end{array}$ \\
\hline Guillard & 0,8420 & 224,830 & 70,631 & $\mathbf{2 9 5 , 4 6 1}$ \\
\hline Walne & 5,5402 & 266,404 & 86,641 & $\mathbf{3 5 3 , 0 4 5}$ \\
\hline
\end{tabular}

Berdasarkan jenis media yang digunakan, kultur yang dikultivasi dengan media Walne lebih banyak mengandung pigmen klorofil dibandingkan dengan media Guillard. Hal ini karena biomassa yang dihasilkan dari kultivasi media Walne lebih banyak sehingga pigmen klorofil yang terkandung dalam biomassa tersebut juga lebih banyak.

\section{Kesimpulan}

Berdasarkan hasil penelitian yang dapat disimpulkan adalah jenis media berpengaruh terhadap konsentrasi biomassa pada mikroalga Nannochloropsis sp, nilai konsentrasi biomassa kering yang dihasilkan yaitu 10,98 $\mathrm{g} / \mathrm{L}$ untuk media Walne dan 5,10 g/L untuk media
Guillard. Kandungan klorofil hasil ekstraksi dari biomassa kering pada mikroalga Nannochloropsis sp. dengan media kultur Walne lebih tinggi dibandingkan dengan media Guillard dengan total klorofil senilai $353,045 \mu \mathrm{g} / \mathrm{mL}$. Sehingga produksi klorofil terbaik adalah kultivasi menggunakan media kultur Walne.

\section{Daftar Pustaka}

1. Cardozo, K., Guaratini, T.,Barros, M., Falcao, V., (2007), Metabolites from Algae with Economical Impact, Article, Comparative Biochemistry and Physiology, Part C, Pharmacology, Toxicology \& Endrocrinology, January 2007, Hal. 61.

2. Hadiyanto, H, S., Elmore, T, V., Gerven, A., Stankiewicz., (2013), Hydrodynamic Evaluation in High Rate Alge Pond (HRAP) Design, Chemical Engineering Journal, 217(1): 231.

3. Isnansetyo, A dan Kurniastuty., (1995), Teknik Kultur Phytoplankton dan Zooplankton, Kanisius, Yogyakarta.

4. Jeffrey, S., dan Humphrey, G., (1975), New Spectrophotometric Equations for Determining Chlorophylls a, b, c1, and c2 in Higher Plants, Algae, and Natural Phytoplankton. Biochem. Physiol. Pflanzen 167 : 191-194.

5. Kawaroe, M., Pratono, T., Sunuddin, A., Sari D. W., dan Agustine, D., (2010), Mikroalga : Potensi dan Pemanfaatannya untuk Produksi Bio Bahan Bakar, IPB Press, Bogor.

6. Pangestuti, R, (2017), Mikroalgae Koleksi P2O LIPI untuk Nutraseutikal Masa Depan, Laporan Akhir Tahunan, Pusat Penelitian Oseanografi, LIPI, Jakarta.

7. Prayitno, J., (2016), Pola Pertumbuhan dan Pemanenan Biomassa dalam Fotobioreaktor Mikroalga untuk Penangkapan Karbon, Jurnal Teknologi Lingkungan 17 (1): 45-52.

8. Riedel, A., (2009), Read Mariculture-instan Rotifers, www.instan-alage.com, Diakses tanggal $10 \mathrm{Mei}$ 2019.

9. Stanley, (2000), Enviromental Chemistry Seventh Edition, CRC Press LLC, USA :149-150. 